\title{
The Development of an Educational Game Tool (APE) Based on Environment for Scientific Learning on Animal Themes for Early Childhood Teachers of Earthquake Victims in Sub-District Narmada, Nusa Tenggara Barat
}

\author{
Nurhasanah $^{1}$, I Nyoman Suarta ${ }^{2}$, Ika Rachmanyani ${ }^{3}$, and Siti Maulida Ababil ${ }^{4}$ \\ ${ }^{1}$ Early Childhood Education Department, University of Mataram, Mataram, Indonesia, nurhasanah@unram.ac.id \\ ${ }^{2}$ Early Childhood Education Department, University of Mataram, Mataram, Indonesia, suarta9@gmail.com \\ ${ }^{3}$ Early Childhood Education Department, University of Mataram, Mataram, Indonesia \\ ${ }^{4}$ Early Childhood Education Department, University of Mataram, Mataram, Indonesia
}

\begin{abstract}
This research is motivated by the earthquake that occurred in August 2018 ago caused a lot of APE were damaged due to damage to the building, exposed to rain, and have disappeared so that the formulation of the problem of this research is how to model the development of APE, forms APE, and group APE-based environment that can be used for scientific study on the theme of animals for early childhood teachers of earthquake victims in the sub-sub-district of Narmada. The purpose of this study is to determine the model of development of APE, forms APE and APE-based environmental group that can be used for scientific study on the theme of animals for earthquake victims early childhood teachers in the sub-sub-district of Narmada. This research is an action research. The pupulation of this study were 87 teachers and $35 \%$ of samples were 30 teachers with sampling using a random sampling technique. The research data was collected by questionnaire, focus group discussions, and documents. Data were analyzed using qualitative descriptive analysis method. These results indicate that the model of development of APE-based environment for learning scientific on the theme of animals can be carried out through four stages of the development model. APE forms-based environment that has been developed by teachers for as much as 7 APE animal themes which are 2 forms of butterfly, 2 forms of fish, one form of a peacock, one form of sheep, and one form of a tortoise. APE shape that can be used in scientific learning is flying butterflies APE.
\end{abstract}

Keywords: APE, Scientific Learning

\section{INTRODUCTION}

In the process of implementation of learning in schools, media or means of educational games are very easy to obtain. Educators can take advantage of the environment to be developed as a tool in the form of educational games used goods or goods that are still in use. Ingredients are sourced from the environment eg sand, clay, wood, leaves and many more materials available in the neighborhood. Utilizing the surrounding environment to be various forms of APE can attract more children in the learning process as well as assisting in the learning scientific process. Scientific Learning is a learning focused on students. Where learners are more active in and can go through stages of scientific learning, ie observe, ask, gather information.

However, the fact that the case in the current field, the implementation of the learning process in the school still has many shortcomings. One drawback is the limited means of educational games for children. So far there are still many in the early childhood institution that provides a find APE instantly by buying on the market. For institutions which have APE, APE often are not used to the maximum, APE used in accordance with the theme of learning, even with the demands of scientific learning. Looking at these conditions it is necessary to do a study or development related to the APE to solve the problems above.

Tectonic earthquake that occurred on the Lombok island in August 2018 caused much damage in the subdistrict of Narmada. One form of damage sustained by the many APE damaged or broken due to damage to the building because it is often exposed to rain. Besides APE too much is lost so that a shortage in supporting the implementation of the learning process. See conditions like this, the researchers initiated a study to take advantage of 
the environment in the development of educational games based tool environment for scientific study on the theme of animals for teachers earthquake victims in Narmada Subdistrict of West Lombok regency.

Based on the background described above, that will be examined in this study can be formulated into two formulations of the problem is: "How to model-based development environment APE for scientific study on the theme of animals for early childhood teachers of earthquake victims in 2019?". While specifically the formulation of the issues raised were: (a) "The forms of APE-based environment how that can be developed for learning scientific on the theme of animals for early childhood teachers earthquake victims in Sub-district Narmada academic year 2019?", And (b) "Group APEbased how the environment can be used for scientific study on the animal theme for the victims of the earthquake early childhood teachers in the sub-district Narmada in 2019?". "How to model-based development environment APE for scientific study on the theme of animals for early childhood teachers Narmada earthquake victims in Subdistrict in 2019?". While specifically the formulation of the issues raised were: (a) "The forms of APE-based environment how that can be developed for learning scientific on the theme of animals for early childhood teachers earthquake victims in Sub-district Narmada academic year 2019?", And (b) "Group APE-based how the environment can be used for scientific study on the animal theme for the victims of the earthquake early childhood teachers in the sub-district Narmada 2019 school year? ". "How to model-based development environment APE for scientific study on the theme of animals for early childhood teachers Narmada earthquake victims in Sub-district 2019 school year?". While specifically the formulation of the issues raised were: (a) "The forms of APE-based environment how that can be developed for learning scientific on the theme of animals for early childhood teachers earthquake victims in Subdistrict Narmada academic year 2019?", And (b) "Group APE-based how the environment can be used for scientific study on the animal theme for the victims of the earthquake early childhood teachers in the sub-district Narmada in 2019?".

The purpose of this study is: To find the model-based development environment APE for scientific study on the theme of animals for early childhood teachers in the subdistrict Narmada earthquake victims' academic year 2019. While specifically the purpose of this study are: (a) To determine the forms of neighborhood-based APE which can be developed for scientific study on the theme of animals for early childhood teachers in the sub-district Narmada earthquake victims academic year 2019. (b) to determine the APE-based environmental group that can be used for scientific study on the animal theme for the victims of the earthquake early childhood teachers in the sub-district Narmada school year 2019.

\section{METHODS}

A. Place and time of research

Researchers conducted a study in the sub-district of Narmada. Researchers took this location because the Subdistrict Narmada is one of the areas affected by the earthquake in August 2018. As a result of these disasters damaged many early childhoods associated with facilities and APE especially for children. The experiment was conducted in April-May 2019.

This type of research used in this study is the kind of action research (Action Research). In the present study, researchers aim to improve APE-based development environment which is consistent with the goals of the research act itself. Teachers also will produce works that shaped APE-based environment for scientific study on the theme of animals as the end result. The population in this study were all early childhood teachers in the sub-district of Narmada, amounting to 87 people spread across 20 schools. Researchers used a simple random sampling technique for the population in this study is not too big.

The population consisted of 87 early childhood teachers in the sub-district of Narmada, the determination of the large-small sample does not use statistical calculations. researchers took a sample of $35 \%$ of the population so that the sample size is $35 \%$ x $87=30$ teachers. Data collection methods used in this study consists of methods: questionnaires, Focus Group Discussion (FGD) and documentation. This research is a qualitative descriptive study conducted with several stages to achieve the research objectives. The stages of research to be conducted is shown in Table 1 .

Analysis of the data using the techniques of qualitative data analysis, is to perform the analysis directly result APE has made teachers the earthquake victims in the sub-district of Narmada to analyze based on forms of APE can be developed to study the scientific on the theme of animals, and grouping APE can be used for scientific study. Data from the questionnaire in this research is quantitative data that were analyzed descriptively in percentage.

\section{RESULT AND DISCUSSION}

The results were obtained data on the questionnaire by the respondents. The questionnaire was used to collect data about APE-based environment that can be developed for scientific study on the theme of animals. Questionnaire began to spread on 8-15 May 2019 to 12 kindergartens in the sub-district Narmada and is completed by 43 respondents. Based on the results of questionnaires obtained, the percentage of APE-based source materials for the environment at the highest animal theme clay which gets a percentage of $100 \%$. While the percentage of APE-based source materials for the environment at the lowest animal theme is aluminum with a percentage of $44 \%$. In addition, respondents also added the source material in the form of paper folding APE manufacture, waste paper, husks, old newspapers, coconut pulp, snail shells, and wipes. 
Table 1. Stages of Research

\begin{tabular}{|c|c|c|}
\hline $\begin{array}{c}\text { stages } \\
\text { Research }\end{array}$ & Research activities & Target Outcomes Research \\
\hline $\begin{array}{l}\text { preparatory } \\
\text { research }\end{array}$ & $\begin{array}{ll}\text { 1. } & \begin{array}{l}\text { Develop research } \\
\text { instruments }\end{array} \\
\text { 2. } & \begin{array}{l}\text { Determination of research } \\
\text { subjects }\end{array} \\
\end{array}$ & $\begin{array}{l}\text { 1. Establishment of research FGD guide. } \\
\text { 2. Establishment of a questionnaire to collect research data. }\end{array}$ \\
\hline \multirow[t]{3}{*}{$\begin{array}{l}\text { implementat } \\
\text { ion research }\end{array}$} & $\begin{array}{l}\text { APE development and data } \\
\text { collection group I }\end{array}$ & $\begin{array}{l}\text { 1. Data gathering APE development model based on a scientific learning } \\
\text { environment for an animal theme for teachers of earthquake victims in the } \\
\text { sub-district of Narmada. } \\
\text { 2. Data gathering APE forms-based environment for scientific study on the } \\
\text { theme of animals for teachers in the sub-district Narmada earthquake } \\
\text { victims. } \\
\text { 3. Data gathering for the environmental group-based APE scientific study on } \\
\text { the theme of animals for teachers in the sub-district Narmada earthquake } \\
\text { victims. }\end{array}$ \\
\hline & $\begin{array}{l}\text { APE development and data } \\
\text { collection in group II }\end{array}$ & $\begin{array}{l}\text { 1. Data gathering APE development model based on a scientific learning } \\
\text { environment for an animal theme for teachers of earthquake victims in the } \\
\text { sub-district of Narmada. } \\
\text { 2. Data gathering APE forms-based environment for scientific study on the } \\
\text { theme of animals for teachers in the sub-district Narmada earthquake } \\
\text { victims. } \\
\text { 3. Data gathering for the environmental group based APE scientific study on } \\
\text { the theme of animals for teachers in the sub-district Narmada earthquake } \\
\text { victims. }\end{array}$ \\
\hline & $\begin{array}{l}\text { APE development and data } \\
\text { collection in group III }\end{array}$ & $\begin{array}{l}\text { 1. Data gathering APE development model based on a scientific learning } \\
\text { environment for an animal theme for teachers of earthquake victims in the } \\
\text { sub-district of Narmada. } \\
\text { 2. Data gathering APE forms-based environment for scientific study on the } \\
\text { theme of animals for teachers in the sub-district Narmada earthquake } \\
\text { victims. } \\
\text { 3. Data gathering for the environmental group based APE scientific study on } \\
\text { the theme of animals for teachers in the sub-district Narmada earthquake } \\
\text { victims. }\end{array}$ \\
\hline $\begin{array}{l}\text { Data } \\
\text { analysis }\end{array}$ & $\begin{array}{l}\text { Analyze the data and draw } \\
\text { conclusions }\end{array}$ & $\begin{array}{l}\text { Mapping of research results in the form of a development model APE, APE } \\
\text { forms, and group-based APE environment for scientific study on the theme of } \\
\text { animals for teachers in the sub-district Narmada earthquake victims. }\end{array}$ \\
\hline Reporting & Develop research report & Establishment of a research report in the form of a thesis. \\
\hline
\end{tabular}

From the results the percentage of material resources APE manufacture of an environmental based on the theme of animals by filling the questionnaire above, researchers divided the source material into two groups namely materials group organic and inorganic materials. Source materials for APE based material group can be seen in the table 2 about group Material APE.

From the table 3 about making materials APE above, the number of APE made by the teacher as much as 7 APE shape of animals including 2 APE shape of a butterfly, 2 APE shape of fish, 1 APE form of a peacock, 1 APE form of sheep, and 1 APE form of a tortoise.

Creation and development of APE in the study carried out by APE development model. This development model consists of four phases namely to identify the source of manufacture APE environment based on the theme of animals, classifying materials APE manufacture environmentally based on animal themes, developing APE based group of materials, then created APE for scientific study on the theme of animals.

Of the four stages of this APE development model, the stages relating to scientific learning is the learning stage for the creation of scientific APE. This last phase will focus on scientific learning. Results of development that teachers APE, APE to be used for scientific study was flying butterflies APE.

This is in accordance with the stages of the first stage of scientific study of children watching animals in the surrounding environment, such as a butterfly. The second phase of children asking for things that have not understood about the butterflies, such as the color, place of life, food, and so forth. The third stage of the children experiment with various materials to gather information about the butterflies. At this stage the child makes the shape of a butterfly using origami paper and stick it on the bottle as if the butterfly is flying. The fourth stage is to start to make sense. In this activity, children can get to know the colors of butterflies that have been made. The last stage of this scientific learning is child retell the results of the activities already done. 
Table 2. Group Material APE

\begin{tabular}{|c|c|c|}
\hline No. & group Material & $\begin{array}{c}\text { List of Names of Materials } \\
\text { Manufacture APE }\end{array}$ \\
\hline \multirow{27}{*}{1.} & \multirow{27}{*}{$\begin{array}{l}\text { organic } \\
\text { materials }\end{array}$} & Wood \\
\hline & & Foliage \\
\hline & & Twigs \\
\hline & & Flower \\
\hline & & Banana trees \\
\hline & & Bamboo \\
\hline & & coconut fibers \\
\hline & & Rocklike \\
\hline & & Sand \\
\hline & & Coral \\
\hline & & Clay \\
\hline & & Cereals \\
\hline & & Cotton \\
\hline & & Sticks \\
\hline & & Paper \\
\hline & & Eggshell \\
\hline & & Nutshell \\
\hline & & Former ice cream sticks \\
\hline & & Where the egg (egg trail) \\
\hline & & used cardboard \\
\hline & & Folding paper \\
\hline & & Scrap paper \\
\hline & & Husk \\
\hline & & old newspaper \\
\hline & & Coconut pulp \\
\hline & & snail shell \\
\hline & & Tissues \\
\hline \multirow{13}{*}{2.} & \multirow{13}{*}{$\begin{array}{l}\text { inorganic } \\
\text { materials }\end{array}$} & Flannel \\
\hline & & Aluminum \\
\hline & & Dakron \\
\hline & & Yarn \\
\hline & & Styrofoam \\
\hline & & Plastic \\
\hline & & Rubber \\
\hline & & Plastic bottles \\
\hline & & Cans \\
\hline & & former pipette \\
\hline & & Close bottles \\
\hline & & Used plastic cups \\
\hline & & Former Compact Disk (CD) \\
\hline
\end{tabular}

\section{CONCLUSION}

Based on the research and discussion above, the researchers conclude:

1. Model development Games Educational Tool (APE) based environment for learning scientific on the theme of animals for early childhood teachers earthquake victims in Sub-district Narmada West Lombok Regency can be carried out through four stages of the development model of the identification of the source materials for APE environmentally based on the theme of animals, grouping materials for APE environment based on the theme of animals, developing APE based group of materials, and the last creation of APE for scientific study.

2. APE forms-based environment that has been developed by teachers for as much as 7 APE animal themes which are 2 forms of butterfly, 2 forms of fish, one form of a peacock, one form of sheep, and one form of a tortoise. APE shape that can be used in scientific learning is flying butterflies APE.

3. APE group-based environment that can be used for scientific study on the theme of animals are a group of organic materials by type of sensorimotor play.

Table 3. APE Making Materials

\begin{tabular}{|c|c|c|c|}
\hline Group & $\begin{array}{l}\text { Name } \\
\text { APE }\end{array}$ & $\begin{array}{c}\text { Name Material } \\
\text { Manufacture APE }\end{array}$ & $\begin{array}{c}\text { Main types } \\
\text { on a Theme } \\
\text { Animals }\end{array}$ \\
\hline 1 & $\begin{array}{l}\text { Flying } \\
\text { butterfly }\end{array}$ & $\begin{array}{l}\text { Types of organic } \\
\text { matter: } \\
\text { a. Origami paper } \\
\text { b. Gravel } \\
\text { Types of inorganic } \\
\text { materials: } \\
\text { a. doll's eyes } \\
\text { b. Plastic bottles }\end{array}$ & sensorimotor \\
\hline 2 & $\begin{array}{l}\text { Collage of } \\
\text { images of } \\
\text { butterflies }\end{array}$ & $\begin{array}{l}\text { Types of organic } \\
\text { matter: } \\
\text { a. HVS } \\
\text { b. Cereals } \\
\text { c. Dried leaves }\end{array}$ & sensorimotor \\
\hline 3 & $\begin{array}{l}\text { Fish } \\
\text { flannel }\end{array}$ & $\begin{array}{l}\text { Types of organic } \\
\text { matter: } \\
\text { a. Origami paper } \\
\text { b. HVS } \\
\text { Types of inorganic } \\
\text { materials: } \\
\text { a. Flannel } \\
\text { b. dacron }\end{array}$ & sensorimotor \\
\hline 4 & $\begin{array}{l}\text { Fish used } \\
\text { CDs }\end{array}$ & $\begin{array}{l}\text { Organic matter: } \\
\text { a. Origami paper } \\
\text { Inorganic materials: } \\
\text { a. CDs former } \\
\text { b. doll's eyes }\end{array}$ & sensorimotor \\
\hline 5 & $\begin{array}{l}\text { peacock } \\
\text { leaf }\end{array}$ & $\begin{array}{l}\text { Organic matter: } \\
\text { a. manila paper } \\
\text { b. Cassava leaves } \\
\text { c. Dry mango leaves } \\
\text { d. Former ice cream } \\
\quad \text { sticks } \\
\text { e. Origami paper } \\
\text { Inorganic materials: } \\
\text { a. Flannel }\end{array}$ & sensorimotor \\
\hline 6 & Sheep & $\begin{array}{l}\text { Organic matter: } \\
\text { a. Cotton } \\
\text { b. Paper head of sheep } \\
\text { Inorganic materials: } \\
\text { a. cotton bud } \\
\text { b. Yakult bottle }\end{array}$ & sensorimotor \\
\hline 7 & Turtle & $\begin{array}{l}\text { Organic matter: } \\
\text { a. Green beans } \\
\text { Inorganic materials: } \\
\text { a. Former sprite bottle } \\
\text { b. Flannel }\end{array}$ & sensorimotor \\
\hline
\end{tabular}




\section{REFERENCES}

[1] Anggito, Albi dan Johan Setiawan. 2018. Metodologi Penelitian Kualitatif.

KabupatenSukabumi: CV Jejak.

[2] Aqib, Zinal dkk. 2011. Penelitian Tindakan Kelas Untuk Guru SD, SLB, TK. Bandung: Yrama Widia.

[3] Ariesta, Riany. 2009. Alat Permainan Edukatif Lingkungan Sekitar. Bandung: PT Sandiarta Sukses.

[4] Ayu, Cheni Chaenida Madu. 2018. Media Pembelajaran Bola KUPINKHIU Meningkatkan Hasil Belajar dengan Pendekatan Saintifik. Gresik: Caremedia Communication.

[5] Darmadi. 2018. Asyiknya Belajar Sambil Bermain. Cibubur: Guepedia.

[6] Direktorat Pembinaan PAUD. 2015.Pedoman Pengembangan Tema Pembelajaran PAUD.

[7] Guslinda dan Rita Kurnia. 2018. Media Pembelajaran Anak Usia Dini. Surbaya: CV Jakad Publishing.

[8] Ismail, Andang. 2009. Education Games. Yogyakarta: Pro-U Media.

[9] Latif, Mukhtar, dkk. 2016. Orientasi Baru Pendidikan Anak Usia Dini. Jakarta: Prenadamedia Group.

[10] Ramadhan, Sarah Zahro N. 2018. "Pengaruh Aktivitas Bermain Menggunakan Bahan Alam Terhadap Kemampuan Mengklasifikasi Benda Pada Anak Usia 5-6 Tahun". Skripsi S1. Universitas Lampung.

[11] Rusman. 2017. Belajar dan Pembelajaran Berorientasi Standar Proses Pendidikan. Jakarta: Kencana.

[12] Sarmanu. 2017. Dasar Metodologi Penelitian. Surabaya: Pusat Penerbitan dan Percetakan Universitas Airlangga.

[13] Seto, Mas Bayu. Fungsi APE Alat Permainan Edukatif Anak Usia Dini. https://www.duniapaud.com/fungsi-ape-alatpermainan-edukatif-anak-usia-dini/. Diakses tanggal 22 September 2018.
[14] Sulastri, Yayu Laila, dkk. 2017. IbM Pembuatan Alat Permainan Edukatif (APE) Ramah Anak Bagi Guru PAUD DI Kota Bandung. Publikasi, 22 Desember 2017.

[15] Suryana, Dadan. 2016. Stimulasi dan Aspek Perkembangan Anak. Jakarta: Kencana.

[16] Suyadi dan Dahlia. 2017. Implementasi dan Inovasi Kurikulum Paud 2013. Bandung: PT Remaja Rosdakarya.

[17] Undang-undang No 20 Tahun 2003 pasal 1 ayat 14 tentang Sistem Pendidikan Nasional.

[18] Waluyo, Djoko Adi \& Anis Listyowati. 2017. Kompendium PAUD. Prenadamedia Group: Depok. 